\title{
IPARI FEJLŐDÉS ÉS MUNKA A TUDÁSALAPÚ TÁRSADALOMBAN
}

\section{INDUSTRIAL DEVELOPMENT AND WORK IN KNOWLEDGE-BASED SOCIETIES}

\author{
Szalavetz Andrea \\ DSc, tudományos tanácsadó, MTA Közgazdaság- és Regionális Tudományi Kutatóközpont Világgazdasági Intézet \\ szalavetz.andrea@krtk.mta.hu
}

\section{ÖSSZEFOGLALÁS}

A cikk a feldolgozóipar digitális átalakulásának a foglalkoztatásra és a munka jellegére gyakorolt hatását vizsgálja.

\section{ABSTRACT}

The paper analyses the impact of industry 4.0 technologies on employment and on the nature of work.

Kulcsszavak: ipar 4.0, kiber-fizikai rendszerek, munkaerőpiac polarizálódása

Keywords: industry 4.0, cyber-physical systems, polarisation of the labour market

\begin{abstract}
„A tajvani Foxconn hatvanezer dolgozóját elbocsátja a kínai leányvállalatától: feladatkörüket robotok veszik át”; „Az Adidas visszaviszi a termelést Németországba, ahonnan húsz évvel korábban vonult ki. A termelést döntően robotok és 3D nyomtatók végzik majd”; „Hangfelismerő és felolvasó szoftver képes tökéletes beszélgetéseket generálni az ügyfelekkel, csökkentve a call centerek üzemeltetési költségeit”; „IBM-algoritmus röntgen-, CT- és EKG-felvételeket elemez: pontosabban és gyorsabban ismeri fel a problémákat, mint az ember."
\end{abstract}

(2016-2017-es hírek)

A hasonló, egyre gyakoribb hírekkel egy időben az elméleti vita is megkezdődött az ún. negyedik ipari forradalom ${ }^{1}$ társadalmi hatásairól, elsősorban arról, milyen körben, mekkora tömegek állását fenyegetik az új technológiai megoldások.

${ }^{1}$ A negyedik ipari forradalom kifejezés egyfelől a hozzáadott értéktermelést forradalmasító új technológiai megoldásokra utal, másfelől arra, hogy új termelési paradigmával állunk szemben, amelyben az értékláncot alkotó számos tevékenység (a termelés és a kapcsolódó szolgáltatási tevékenységek, vállalati folyamatok) jellege megváltozik (részletesen: Szalavetz, 2017). 
A klasszikus hivatkozás Carl Benedikt Frey és Michael A. Osborne (2013) tanulmánya. A szerzők 702 foglalkozást helyeztek nagyító alá abból a szempontból, hogy milyen képesség- és tudásigényű feladatok ${ }^{2}$ társíthatók hozzájuk, és milyen mértékben sztenderdizálhatók ezek a feladatok, majd felbecsülték, hogy az egyes foglalkozások milyen valószínúséggel automatizálhatók. Azt találták, hogy az ipari robotok megjelenése és a mesterséges intelligencia az amerikai foglalkoztatottak 47 százalékának állását veszélyezteti.

A tanulmány óriási visszhangot váltott ki. A reakciók két irányból érkeztek. Egyfelől, több országban elvégezték ugyanezeket a számításokat, és hasonló eredményekre jutottak: Németországban például 42\%-ot mértek (Bonin et al., 2015).

Másfelől, sokan vitatták, bírálták a két közgazdász közelítését, azt állítva, hogy ezek a számítások túlbecsülik az állásvesztés várható arányát (Autor, 2015). Az automatizálás nem teljes foglalkozásokat szüntet meg, hanem csupán bizonyos tevékenységeket vált ki. Viszonylag kevés az olyan munkakör, ahol a feladatok $80 \%$-a vagy annál nagyobb aránya is automatizálható (gondoljunk a Moravec-paradoxonra! - lásd erről: Autor, 2015). Ennek megfelelően más közgazdászok jóval kisebb számokat jeleztek elöre, például az OECD egyik kiadványa szerint a fejlett országok körében a munkahelyek átlagosan 9\%-a szünik meg a negyedik ipari forradalom technológiái következtében (Arntz et al., 2016).

Az új technológiák elterjedése - érvelnek mások - új munkahelyeket is teremt: viszonylag jelentős foglalkoztatásbővülés várható például az ipari robotok gyártói, szervizelöi, üzembe helyezői körében, a kiberfizikai rendszerek infrastrukturális szolgáltatói körében, beleértve e rendszerek biztonságával kapcsolatos megoldások szállítóit. Bővül az üzleti intelligenciával kapcsolatos tevékenységekben foglalkoztatottak köre, nő a 3D- és egyéb tervezők, csakúgy, mint az kiberfizikai termelési rendszerek technikusai, programozói és specialistái számára kínált állások száma. Új szakmák, munkakörök jönnek létre, amelyek ma még nem látható mennyiségü munkahelyet teremtenek (például kiberbiztonsággal kapcsolatos munkakörök, platformfejlesztők, adatbányászok). Az új helyzet továbbá jogi és szabályozási kérdéseket is felvet: az ezzel kapcsolatos munkahelyek száma is nő. Az új technológia termelékenységi és növekedési hatásai következtében szintén jelentős számú új munkahely keletkezhet.

Amint látjuk, végtelenségig tartó számháború kezdődött (lásd még: AtkinsonWu, 2017; Michel-Bivens, 2017), ami azért értelmetlen gyakorlat, mert rengeteg a nyitott kérdés. Egyrészt, a gyors technológiai fejlődés következtében egyre nő

\footnotetext{
${ }^{2}$ Például érzékelés, kézügyesség, fizikai erőkifejtés, írásos szövegértés és a beszélt nyelv megértése, digitális ismeretek, információszerzés és -átadás, interperszonális intelligencia, érvelés, problémamegoldás, absztrakt gondolkodás és elemzés, kreativitás.
} 
azoknak a munkaköröknek a száma, ahol a feladatok 80-90\%-a automatizálható. ${ }^{3}$ Az elvesző munkahelyek számát ugyanakkor az országok intézményi és szabályozási környezete erősen befolyásolja: lassíthatja, de fel is gyorsíthatja a folyamatokat. Másrészt, ma még nem látható mennyiségben és változatossággal jönnek létre új, korábban nem létezett munkakörök, de az így teremtett állások mennyisége és földrajzi megoszlása az egyes országok oktatási rendszerének teljesítményétől függ.

Az elvesző munkahelyek számával kapcsolatos aggodalmakat árnyalja egyes robotgyártó cégek frappáns szlogenje: We take the robot out of the human, vagyis a nehéz, veszélyes, szennyező, unalmas, repetitív munkákat (a munka robot részét) automatizálják - maradnak a viszonylag érdekesebb, nagyobb kreativitást igénylő feladatok.

Két magyarországi történet kívánkozik ide. Egy robotokat szállító cég vezetője mondta a következőt: „Én még olyan gyártóval nem találkoztam, ahol a dolgozók szemrehányást tettek volna, hogy miért telepítünk ide robotokat. Nemrég például egy nyugat-magyarországi öntöüzemben robotokra cserélték az öntőformába a folyékony fém beöntését és egyengetését végző dolgozókat. El tudja képzelni, milyen feladatokat váltottak ki robotokkal? Hány fokban kellett dolgozni, mekkora súlyokat emelgetni? Az ott dolgozókat lényegesen könnyebb fizikai feladatokat igénylő munkákra irányították át."

A második történet egy magyarországi autóipari cégről szól, amely az iparág más szereplőihez (és más iparágakéihoz hasonlóan) súlyos munkaerőhiánnyal küzd, emiatt robotokat szerzett be. Tapasztalatai a vártnál is kedvezőbbek voltak: a beruházás gyorsan megtérült: nem volt váratlan leállás, például betegszabadság miatt, nem került az adott ponton hiba a folyamatokba.

Az elméletre visszatérve, abból kell kiindulnunk, hogy nem az álláshely a javasolt elemzési alapegység, hanem a feladatkör. Az ipar 4.0 technológiák nem megszüntetik, hanem újradefiniálják a munkaköröket: az egyes munkakörök jelenlegi betöltéséhez szükséges tudás és képességek köre változik. Az ipar 4.0 technológiák jellemzően a középszintű és a magas bérezésủ munkakörökben folytatott tevékenységet alakítják át, drámai mértékben növelve azok termelékenységét. A termelési rendszerek virtuális modellezése például könnyebbé teszi a gyártósorok tervezését, a termelési folyamatok optimalizálását. A szoftveralapú kapacitástervezési és termelésütemezési megoldások a középvezetők munkáját támogatják.

Ahol éves szinten többezerféle termék gyártása folyik, létszükséglet, hogy az átláthatóságot javító döntéstámogatási rendszereket szerezzenek be. Az ipari

\footnotetext{
${ }^{3}$ Napjainkban többek között a raktárosok, anyagmozgatók, soförök, marósok, forgácsolók, hegesztők, meghatározott minőségellenőrök, könyvelők stb. munkája automatizálható már technikailag 80\%-ot meghaladó mértékben.
} 
4.0 megoldások nem csupán pontosan jelzik, hogy áll a termelés menete, várhatók-e szük keresztmetszetek az alkatrészkészletben, de optimalizálnak is: kiszámítják, milyen ütemezésben, hova kell allokálni a kapacitásokat. A kiber-fizikai rendszerek jelzik és nyilvántartják, melyik termelőeszköz milyen ütemben kopik, mikor lesz szükség a karbantartására, alkatrészcserére.

Ezek a megoldások amellett, hogy javítják az erőforrás-felhasználás hatékonyságát, az intuícióra, szakmai tapasztalatokra épülő mérnöki, középvezetői rejtett tudást sztenderdizálják, automatizálják: bizonyos feladatokat átvesznek, vagyis feleslegessé tesznek.

A termelőeszközök, a termelési folyamatok és a termékek minden releváns paraméteréről adatokat gyüjtő és feldolgozó megoldások kimutatnak korrelációkat: korábban a rendszert akár hetekig is kellett a mérnököknek elemezni, hogy rájöjjenek, miért keletkeztek a termelési problémák, miért jött le selejt a sorról. Az intelligens algoritmusok elvégzik a nagy mennyiségủ adat elsődleges kiértékelését, kimutatják azokat a „sủrüsödési pontokat”, „mintázatokat”, amelyekre oda kell figyelni például a karbantartások ütemezése során, vagy amelyek beavatkozást igényelnek, mert a problémák gyökerei valószínüleg ott rejtőznek. Az ipar 4.0 megoldások tehát nem veszik át teljes egészében a mérnöki munkát, csupán megkönnyítik, támogatják. ${ }^{4}$

A feldolgozóipar digitális átalakulása nem elsősorban a fizikai foglalkoztatottak feladatainak automatizálása miatt jár látványos termelékenységemelkedéssel, hanem a közép- és felsőszintü tudást igénylő feladatkörök részleges automatizálása és támogatása következtében.

Természetesen az érem másik oldalát is figyelembe kell venni. Kutatók a munkaerőpiac folytatódó, sőt erősödő polarizálódását vetítik elöre (például: Goos et al., 2014; ellenvéleményt képvisel Michel-Bivens, 2017). A munkaerőpiaci kereslet átrendeződik: a rutin, vagyis az automatizálható feladatokat végzők iránti kereslet visszaesik. A tapasztalatok azt mutatják, hogy az automatizálás és a mesterséges intelligencia miatt végleg elvesző állások nem a legalacsonyabb szaktudást igénylő munkakörök: a robotok szakmunkások feladatait veszik át, a mesterséges intelligencia a közepes szaktudást igénylő szellemi rutinmunkát váltja ki.

Az állásukat vesztett alacsony szaktudású foglalkoztatottakat részben felszívhatják az egyelöre nem automatizálható feladatokból álló, alacsony szaktudást igénylő munkakörök a szolgáltatási szektorban (Moravec-paradoxon). A közepes szaktudású munkanélkülivé vált tömegek számára azonban ez nemigen jelent megoldást, mivel ezeknek az alacsony szaktudást igénylő szolgáltatási munkakö-

\footnotetext{
${ }^{4} \mathrm{Az}$ intelligens megoldások a fizikai dolgozók munkáját is támogatják, például a raktárosokét és anyagmozgatókét, akik vonalkódolvasóval a kezükben szedik le a megfelelő alkatrészeket, és mobiltelefon-applikációk segítik őket abban, hogy milyen sorrendben haladjanak a raktárban.
} 
röknek az átlagos bérszintje alacsonyabb, mint amekkora a korábbi szakmunkásoknak, a rutinmunkát végző, irodai vagy egyéb szolgáltatásban dolgozó alkalmazottaknak vagy a középvezetőknek volt.

A munkaerőpiac polarizációja összességében tehát azt jelenti, hogy a legalacsonyabb szaktudást igénylö, nem automatizálható feladatok iránti kereslet nem csökken, sőt, enyhén növekszik, ugyanakkor e foglalkoztatottak bérezése minimális. Ezzel párhuzamosan erősen nő a csúcskategóriás szaktudást igénylő, kimagaslóan fizetett munkakörökben foglalkoztatottak iránti kereslet és ennek megfelelően a bérük is. A legnagyobb vesztesek a középszintű szaktudást igénylő munkakörökben foglalkoztatottak lesznek: az automatizálás és föként a mesterséges intelligencia az ő munkakörüket fenyegeti leginkább.

Mindazonáltal látnunk kell, hogy a statisztikákban kimutatott (például Goos et al., 2014) eddigi polarizáció nem a negyedik ipari forradalom hatására ment végbe, hanem a globalizáció következményeként, pontosabban, a feldolgozóipari és az ahhoz kapcsolódó támogató tevékenységek kiszervezése/kihelyezése következtében. Az új technológiák hatása valószínüleg csak a 2020-as évektől lesz majd kimutatható.

A polarizációval kapcsolatban további kutatást igényel, hogy vajon a foglalkoztatás szerkezetének változása továbbra is U alakú görbével írható-e le, vagyis továbbra is nő-e az alacsony képzettségü foglalkoztatottak iránti kereslet is. Olyan forgatókönyv is elképzelhető, hogy az U bal oldali szára eltünik, amennyiben a technológia további fejlődésével (Pratt, 2015) a kevés szakképzettséget igénylő, de ma még nehezen automatizálható feladatokat is automatizálják (háztartási robotok, egészségügyi robotok, szállításban, kézbesítésben alkalmazott robotok, kiskereskedelemben alkalmazott robotok). Ez esetben az új technológiai megoldások társadalmi, politikai hatása valóban drámai lehet.

E forgatókönyv megvalósulásának esélye a technológiai fejlődés sebességétől, az új megoldásokat megtestesítő termékek árának alakulásától és az intézményi változásoktól függ.

Ezzel párhuzamosan az egyes szakképzettségi kategóriák (alacsony, közepes, magas) tartalma átalakul (például ami ma közepes szaktudásnak felel meg, holnapra az alacsony kategóriába kerülhet), vagyis a munkaerő-kereslet szerkezetének változása nem egyszerüsíthető le feltétlenül arra, hogy az eddigi polarizálódási tendenciák folytatódnak, erősödnek. Ráadásul, ahogyan azt David H. Autor (2015) bemutatja, hogy a legutóbbi években a legmagasabb szaktudást igénylö munkakörökben foglalkoztatottak iránti kereslet növekedése is lelassult (a digitális átalakulás az ö feladataik egy részét is automatizálta). Összességében, az eddigi folyamatokat (a polarizációt) leíró U-görbe sokat változhat, és nem egyértelmü, hogy az U mélyülni fog. 


\section{IRODALOM}

Arntz, M. - Gregory, T. - Zierahn, U. (2016): The Risk of Automation for Jobs in OECD Countries: A Comparative Analysis. OECD Social, Employment, and Migration Working Papers, No. 189. Paris: OECD Publishing, DOI: 10.1787/5jlz9h56dvq7-en https:/goo.gl/VUfMxY

Atkinson, R. D. - Wu, J. (2017): False Alarmism: Technological Disruption and the U.S. Labor Market, 1850-2015. (ITIF@Work Series) http://www2.itif.org/2017-false-alarmism-technological-disruption.pdf

Autor, D. H. (2015): Why Are There Still So Many Jobs? The History and Future of Workplace Automation. The Journal of Economic Perspectives, 29, 3, 3-30. DOI: 10.1257/jep.29.3.3 https:// economics.mit.edu/files/11563

Bonin, H. - Gregory, T. - Zierahn, U. (2015): Übertragung der Studie von Frey/Osborne (2013) auf Deutschland. ZEW Kurzexpertise, No. 57. Mannheim: ZEW, ftp://ftp.zew.de/pub/zewdocs/gutachten/Kurzexpertise_BMAS_ZEW2015.pdf

Frey, C. B. - Osborne, M. A. (2013): The Future of Employment: How Susceptible Are Jobs to Computerisation? Working paper. Oxford: Oxford Martin School, http://www.oxfordmartin. ox.ac.uk/downloads/academic/future-of-employment.pdf

Frey, C. B. - Osborne, M. A. (2017): The Future of Employment: How Susceptible Are Jobs to Computerisation? Technological Forecasting and Social Change, 114, 254-280. DOI: 10.1016/j. techfore.2016.08.019, http://www.sciencedirect.com/science/article/pii/S0040162516302244

Goos, M. - Manning, A. - Salomons, A. (2014): Explaining Job Polarization: Routine-biased Technological Change and Offshoring. The American Economic Review, 104, 8, 2509-2526. DOI: 10.1257/aer.104.8.2509, https://www.researchgate.net/publication/265172769_Explaining_Job_ Polarization_Routine-Biased_Technological_Change_and_Offshoring

Michel, L. - Bivens, J. (2017): The Zombie Robot Argument Lurches on. Economic Policy Institute, http://www.epi.org/files/pdf/126750.pdf

Pratt, G. A. (2015): Is a Cambrian Explosion Coming for Robotics? Journal of Economic Perspectives, 29, 3, 51-60. DOI: 10.1257/jep.29.3.51, http://pubs.aeaweb.org/doi/pdfplus/10.1257/ jep.29.3.51

Szalavetz A. (2017): Ipar 4.0 technológiák és környezeti fenntarthatóság - magyar feldolgozóipari tapasztalatok. Külgazdaság, 61, 7-8., 28-45. 